\title{
Chapter Twelve: The State-Issue of Currency without Usury
}

\author{
By Peter Challen, Simon Mouatt \& Rodney Shakespeare
}

'The intrinsic values of real economy must be those that work for everyone and protect the earth...' Canon Peter Challen

\section{Introduction}

We humans are in the midst of a potentially terminal economic, social and environmental crisis. In order to address that crisis this chapter outlines a proposal for the structural reform of a national monetary system, with practical and beneficial consequences. It is recognised, of course, that monetary reform per se is not a holistic panacea to all of our global ills. Yet, it is hoped that the incremental transition recommended, using the national bank to issue interest-free currency (credit-money), could promote the cause of social and economic justice through a more sustainable monetary system. In addition, interest-free currency could be used to finance other reform proposals such as the spread of capital ownership or the creation of a basic income. At the core of the reform is the insight that, usury (defined here as an interestcharge in excess of justifiable administration cost) is not necessary. Whilst it can be argued that administration charges, collateral and properly conceived repayment plans are imperative for the proper functioning of credit markets, usury is not so easily defended (especially for state expenditure) unless the motive is to profit the private financial sector and their investors.

These ideas, of course, resonate with the great religions of Islam, Christianity and Judaism that have a historical tradition of opposing usury on ethical grounds. Yet, in recent centuries, the faiths have compromised these values and therefore been complicit in the levying of usury as capitalist credit relations have evolved. Sadly, we appear to be stuck with debt and the interest it generates. We are presently informed by the economics profession that there is no alternative method of recycling monies from surplus to deficit agents that will practically provide the necessary liquidity for the efficient operation of a modern free-market economy. Yet, interest diminishes the consuming capacity of a borrower (and, when compounded, can eliminate it altogether) thereby breaching the basic market principle that producers should be able to spend the income emanating from their production. Indeed, as Magrit Kennedy has observed, interest also instigates an inflationary tendency and is generally responsible for the exacerbation of global income disparities (Kennedy 1995). Ironically, if a modern government were to seek to expand its income redistributive function, through the expansion of tax, this would be fiercely resisted. Yet, as El Diwany notes, the usurer extracts substantial tribute from the productive economy and this income-stream, in contrast to wealth held in other forms, is not subject to the universal principle of entropy (El Diwany 2003). For money rentiers this means that there is an increasing accumulation dynamic through time that, in conjunction with bank consolidation, helps form what Lenin referred to as a 'financial oligarchy' which then wields an increasing amount of social power in world affairs (Lenin 1996). Meanwhile debt, and its associated suffering, reaches epidemic proportions. Is there a way out? The proposal outlined here suggests that there is but, first, let us consider the activities of creditors (and their extraction of usury) in closer detail. 


\title{
Creditors and Usury
}

The historical practice of usury has had serious practical consequences, which inevitably raised ethical debates. Marx (page 740) cites this passage from Martin Luther (Marx 1976).

\begin{abstract}
'The heathen were able, by the light of reason, to conclude that a usurer is a double-dyed thief and murderer. We Christians, however, hold them in such honour, that we fairly worship them for the sake of their money... Whoever eats up, robs and steals the nourishment of another, that man commits as great a murder (so far as in him lies) as he who starves a man or utterly undoes him. Such does a usurer, and sits the while safe on his stool, when he ought rather to be hanging on the gallows, and be eaten by as many ravens as he has stolen guilders, if only there were so much flesh on him, that so many ravens could stick their beaks in and share it. Meanwhile, we hang the small thieves...Little thieves are put in the stocks, great thieves go flaunting in gold and silk...Therefore is there, on this earth, no greater enemy of man (after the devil) than a gripe-money, and usurer, for he wants to be God over all men. Turks, soldiers, and tyrants are also bad men, yet must they let the people live, and confess that they are bad, and enemies, and do, nay, must, now and then show pity to some. But a usurer and money-glutton, such a one would have the whole world perish of hunger and thirst, misery and want, so far as in him lies, so that he may have all to himself, and every one may receive from him as from a God, and be his serf for ever more. [This is what gladdens his heart, and also] to wear fine cloaks, golden chains, rings, to wipe his mouth, to be deemed and taken for a worthy, pious man...Usury is a great huge monster, like a were-wolf, who lays waste all, more than any Cacus, Gerion or Antaeus. And yet decks himself out, and would be thought pious, so that people may not see where the oxen have gone, that he drags backwards into his den. But Hercules shall hear the cry of the oxen and of his prisoners, and shall seek Cacus even in cliffs and among rocks, and shall set the oxen loose again from the villain. For Cacus means the villain that is a pious usurer, and steals, robs, eats everything. And will not own that he has done it, and thinks no one will find him out, because the oxen, drawn backwards into his den, make it seem, from their footprints, that they have been let out. So the usurer would deceive the world, as though he were of use and gave the world oxen, which he, however, rends, and eats all alone... And since we break on the wheel, and behead, highwaymen, murderers, and house-breakers, how much more ought we to break on the wheel and kill...hunt down, curse, and behead all usurers.' (Martin Luther, 1540, An die Pfarrherrn, wider den Wucher zu predigen).
\end{abstract}

These are strong words from Luther but they contain several points worthy of discussion. Firstly, he suggests that the heathen is capable of identifying the crime of usury whilst, the religious person is not, suggesting that religion is in consort or denial with the lenders. This is consistent with Marx's own analysis whereby religious leaders, through acquiescence towards the ruling order, condone injustice by default and assist in the appeasement of the masses. Marx is perhaps misrepresented as opposing Christianity when, instead, he may be simply opposing religious hypocrisy. Secondly, Luther argues that usurers extract a surplus from the productive sector and likens this to theft on a grand scale. This view can be contrasted, of course, with the bourgeois notion of money-lenders as 'capital providers', who receive an income (interest) for their service to production. A small reward for rentiers would probably be uncontested but, as Lenin noted (page 53), the usurer's return on monies lent (combined with bank fees) often greatly exceeds the surpluses of productive capitalists and helps to form the 'financial oligarchy'(Lenin 1996). Another interesting detrimental consequence of usury, as Francis Bacon had long ago observed, is that, in order to receive income, the usurer does not need to extend energies and attributes towards the productive sector, and, therefore, society is denied the benefit of their unused resources (Roll, 1973).

This image of a thief is continued with Luther's use of Greek mythology, where the popular hero Hercules frees society from the fire-breathing monster Cacus, who is stealing from everyone for his own consumption. Hercules had previously been given a task by Eurystheus to defeat the three-bodied Geryon who had a herd of oxen that, perhaps, could be considered to be analogous to the resources required by the productive economy. Whilst returning with 
the spoils, Hercules had some of the cattle stolen by Cacus. It is interesting that he tried to conceal the crime by dragging the oxen backwards into his cave, to give the impression that they had moved in the other direction. Hercules becomes wise to this and defeats Cacus (Linderman, 1997). Perhaps the modern usurer manages to conceal their activity (crime) because the common understanding is that there is no alternative to credit (nowadays, of course, created ex nihilo by private bankers) and, consequently, debate rarely takes place. When Hercules comes to defeat the giant Antaeus (son of Gaia and Poseidon), who had been terrorising society, he becomes wise to the secret of Antaeus's strength - 'mother earth'. Having unearthed the secret, Hercules is able to lift him off the ground and strangle him.

\section{The History of Monetary Reform}

There are various campaigning groups and individuals, who have studied the mechanics of credit and, to use the Lutheran analogy, 'unearthed' its secrets. These monetary reform groups have threatened to undermine the prevailing monetary vested interests and have therefore, unsurprisingly, been resisted. The reformers have generally proposed to replace the current fractional reserve system, where private banks issue credit-money ex nihilo, with either debt-free fiat money or interest-free credit-money (or some combination of the two) both of which could be issued by the state. Modern monetary reform has antecedents that can be traced back to the events leading to the 1776 American War of Independence. Ellen Brown explains how the American people, controlled by British colonialists, having to pay endless financial tribute to England and faced with shortages of money, had issued their own paper currency (Brown 2007). The paper currencies then lead to a sustained period of productive stability, poverty-alleviation and full-employment. Indeed, on a visit to England, Benjamin Franklin noticed the relative level of poverty and unemployment that existed in London and attributed this to a private debt-based (scarce) money system. When asked to explain the relative prosperity of the American colonies he stated that the issue of paper money by the authorities was the reason for economic success, providing that it was created:

'.... in proper proportions to the demands of trade and industry ...we also [emphasis added] issue it to pay the government's approved expenses and charities. We make sure it is issued in proper proportions to make the goods easily pass from the producers to the consumers...In this manner, creating for ourselves our own paper money, we control its purchasing power, and we have no interest to pay to no one. You see, a legitimate government can both spend and lend money into circulation, while banks can only lend significant amounts of their promissory bank notes, for they can neither give away nor spend but a tiny fraction of the money people need. Thus, there is always a debt principal to be returned and usury to be paid. The result is that you have always too little credit in circulation to give the workers full employment. You do not have too many workers, you have too little money in circulation, and that which circulates, all bears the endless burden of unpayable debt and usury...'

(Brown 2007)

Franklin's statement clearly posits the view that sensible state control, regulation and issue of money, with a restrained role for the private banking sector, were the preferable options. Under the 'Pennsylvania plan', for instance, the colonial authorities had issued debt-free money for government projects, in place of taxes, and also discovered that it was noninflationary. In addition, credit monies were provided for the private sector at five per cent interest rather than the more prohibitive eight per cent charged by the private bankers. The colonial financial system was heralded as a success in Pennsylvania (and other colonies) but, unfortunately, in New England, an over-issue of notes led to the currency's depreciation and this began to affect the investments of British merchants. The result was that, in dealing with the colonial issue in 1751 Britain, also being anxious to retain the colonies in their role as 
suppliers of raw materials, issued a decree banning the issue of new paper money in New England, forcing the local people to borrow from the English bankers abroad. Within a year, Franklin noted, beggars had returned to the streets and, soon, anger began to rise eventually resulting in sufficient revolutionary fervour to challenge the British in the 1776 War of Independence.

The benefit (and need) of sufficient circulating liquidity is a recurrent theme in history. Thus, during the Keynesian 'golden-age' era of the fifties and sixties, for instance, the availability of 'cheap money' (low interest rates) is often cited as a major contributing factor to the prevailing (favourable) macroeconomic climate (Pettifor 2006). Even the monetarist Friedman had cited the Federal Reserve credit squeeze, and subsequent lack of money, as the key contributory factor to the 1930s Depression (Friedman 1956). It appears that the lack of liquidity is often the prelude to economic strife, leading to political and social instability. The debt-based money system, controlled by the private banking infrastructure, is seen as the root cause of the lack of liquidity by contemporary monetary reformers. When interest-bearing credit-money is created, through the production of loans by the banks, there is enough circulating currency to repay the principal of the loan but not to repay the interest. ${ }^{\mathrm{i}}$ This results in the so-called 'impossible contract' and so, the economic system then relies upon the further expansion of credit in order to service existing debt and provide liquidity. If compounded interest is also taken into consideration the problem is far worse The anti-debt campaigner, Ann Pettifor, has likened this (impossible) credit process to a game of 'musical chairs' where the inevitability of default is intrinsic to the system as someone is expected to be left 'holding the chair' (Pettifor 2006). In short, as credit-money grows in relation to fiat money, the problem deepens. At the time of WWII, 'high-powered' money (mainly notes and coins) constituted approximately 50 per cent of the money supply whereas it now only constitutes three per cent in the UK, and less than one per cent in the US (Shakespeare 2002). Firms, consumers and governments all need to find additional revenue in order to meet debt interest payments and this puts substantial pressure on prices, resources and the environment (Kennedy 1995).

The 'fractionally-backed' gold certificates of the goldsmiths, as an early form of credit money, have often been suggested as antecedents for modern (private) commercial banking. Yet, whilst the goldsmiths had to ensure that issued notes were an appropriate multiple of guarded specie deposits in the vaults, their modern private banker counterparts are not subject to de facto reserve restraints. Today, when commercial banks make loans they simply press computer buttons to make accounting entries on their assets and liabilities sheets and so the (subsequently circulating) deposit bank-monies are literally created ex nihilo, that is, out of nothing. The view that bank deposits are initially formed from pre-existing monies is completely fallacious. In short, today's money is created and issued by the banks in response to a request for its creation (Rochon 1999; Howells 2008).

In explaining how this began, United Kingdom monetary reformers further point to the Free Coinage Act of 1666 which enabled the issuance of money by the private banks, thereby starting to replace the English government 'tally-stick' system of accounting. Following the Glorious Revolution of 1688, which installed William of Orange as King, the development of the Bank of England in 1694 granted private investors license to produce legal tender (that is, permission to create money ex nihilo) in order to lend to the government and business. Hitherto, the English monarchs (or their agents) had been responsible for their own currency issue, and so 1688 was really a 'glorious' revolution for the bankers who had succeeded in legitimising their position as official creators of interest-bearing money. This new money, 
issued by private banks as interest-bearing debt, then began to serve as legal tender money, thereby establishing today's statutory and common-law currency practice that permits a de facto private banking cartel to be able to extract substantial tribute from the wealth and income of the productive economy. Whilst the state has experienced periods of stronger intervention in monetary matters, such as the period following the Great Depression, this has been short-lived. Soon after, as Helleiner noted, the private bankers (and sympathetic politicians) were vociferous in lobbying for an increased role for the commercial banks (relative to the state) in the financial system. The financiers particularly pushed for substantial market deregulation that has led to, arguably, potential (and actual) de-stabilising effects to both the state and society's productive structure (Helleiner 1994).

The situation today is such that the levels of consumer, corporate and state debt have reached such alarming proportions that it will not be long before the interest cannot be paid and so the debt will quickly become unsustainable. The largest debtor in the world today, for instance, is the United States, with federal debt alone presently running at $\$ 7.713$ trillion in 2007, and at current trends predicted to reach 'unsustainability' within the next few years as annual interest exceeds taxation receipts. Since the US dollar is used as the global reserve currency, with foreign central banks and institutional investors holding substantial amounts, the ramifications of a major debt default and subsequent dollar devaluation are colossal.

\section{The Current Monetary Reform Movement}

Monetary reformers generally agree on the nature of the perceived international problems but posit varying proposals for the transformation of domestic financial systems. Stephen Zarlenga for instance, from the American Monetary Institute based in Chicago, suggests that the state should create a legally sanctioned 'money of account' that gradually replaces creditmoney to become 100 per cent of the money supply. The money is provided interest and debt-free (Mouatt 2008). Joseph Huber and James Robertson in their 2000 book Creating New Money also propose a debt-free issuance for the purposes of government expenditure (Huber 2000). Under these proposals the money is not backed by specie, only by the force of law. The private banks are also only permitted to conduct lending on a $100 \%$ fractionally backed system, which means they can only lend their own money (investor capital) and/or, with permission, that of depositors, but may not create new money as they do today. This necessitates, of course, much stronger state (financial) intervention.

Yet, there are critics of the Zarlenga type of proposal. The veteran Canadian reformer William Krehm, for instance, opposes the Zarlenga 100 per cent fractional backing approach on the ground that this would lead to a centralization of financial power in the hands of the state that, at least potentially, may lead to state abuse. He favours instead a 50/50 system, where the currency issuance (before circulation) is shared between the state and private banks, that will deliver many of the benefits of reform yet maintain a (safer) plurality of social power through public and private involvement in the money-issue (McConnachie 2006).

The Islamic world also has monetary reform proposals, where interest (riba) is forbidden by Koranic law. The literal translation of riba is increase, although it is usually understood as interest which can be extracted when credit is extended or derived from trade. This, of course, presents difficulties for today's Islamic economic policy-makers (and bankers) who are seeking to implement religious law as well as creating problems for Moslems living in non- 
Islamic financial systems. This is because when monies are provided in the form of credit there needs to be incentives for parting with liquidity (whenever credit is derived from existing deposits) and the levying of administration costs, even without the extraction of profit for financial rentiers. In order to do this, and to be allegedly following Islamic injunction against riba, Islamic Banking has evolved over the last forty years and its general characteristic is that interest is not charged yet, by the use of different legal contracts, other charges are levied that compensate for this (El Gamal 2006).

Notwithstanding policy differences, most monetary reformers (including Islamic reformers) claim that their proposed measures will be anti-inflationary on the grounds that the principal cause of inflation (usury) would be removed. By implication, therefore, the reformers also challenge the mainstream conception of the causes of inflation, which presuppose 'quantity theory of money' explanations, and emphasise instead the substantive role of debt-driven inflation. This 'debt-driver' theory posits that the interest on debt reduces incomes and revenues, and subsequently creates pressures to raise prices and wages in order to compensate thereby inducing inflation. It is also considered, as Adams has noted, that debt puts pressure on the environment, since the need to repay interest as well as the principal necessitates a greater level of economic activity than would otherwise occur (Adams 1991).

\section{The Case for Interest-Free Currency Issue}

The authors argue that interest-free monetary reform proposals are preferable to debt-free policies for several reasons. Firstly, debt-free issuance implies that there is no specific limit to the amount of currency that could be created, which increases the likelihood of moral hazard, that is, the lack of suitable sanctions to mitigate irresponsible spending or profligacy. There may, for instance, be a lack of adequate constitutional safeguards preventing an ambitious state from constructing luxurious state buildings or increasing the wealth of politicians. Governments do not, unfortunately, have a very good historical track record in this regard.

Secondly, with debt-free issuance there is no incentive for state expenditure to be conducted in an efficient manner. Given the depletion of finite resources today, not to mention environmental concerns, this is a really important consideration. Credit-money, albeit without the interest, creates an incentive for monetary discipline since the money needs to be repaid.

Thirdly, debt-free issuance can be considered fiat money, since it remains in circulation rather than being retired in the manner of credit-money. This means that there could be a tendency for economic agents to hoard part of the money-stock, thus creating circulation blockages to the detriment of an efficient real economy. In addition, this may facilitate the creation of money elites (or even a plutocracy), which wield social power deriving from their cartelisation of the monetary entity, similar to the role of specie during the mercantilist era.

Fourthly, the interest-free issue of credit-money is, arguably, less likely to be inflationary. In contrast to the present system, it is posited that both of the monetary reform proposals are likely to mitigate inflationary pressure since there is no interest to pay. However, given that interest-free money is 'created for purpose' and then retired from circulation, there is less likely to be an excess of monies in circulation that could trigger aggregate demand (otherwise not occurring) and subsequently raise prices. 
Finally, given the realpolitik of the political process, debt-free proposals are too revolutionary and threaten monetary vested interests with virtual extinction. It is suggested here that interest-free issuance of currency is more likely to resonate with the values of diverse groups in society, ensure a future for the private banking sector and achieve a general political consensus for reform. In addition, the interest-free proposal outlined below is reasonably close to the proposals that Keynes, popular in many circles, put forward in the thirties.

\section{A Proposal for National Bank-issued Interest-free Loans}

In this plan, conventional interest-bearing loan money is gradually phased out (or reduced), as debt time-contracts are resolved, and is replaced by state issued interest-free currency produced to finance the government budget deficit or capital projects. State issued creditmoney could then circulate as money in the same way that bank deposit currency does today (in conjunction with private credit monies) only without the interest. Interest-free loans (arguably) combine efficiency with social and economic justice. They are directly related to the real economy, made repayable and, when repaid, the monies are then cancelled thus ensuring that productive assets always provide tangible backing to a society's currency. Crucially, because interest is not necessary, the loans allow capital projects to be constructed for a fraction of the present cost. This is the key attraction. Moreover, the loans do not create an inflationary pressure. In the case of public capital projects (such as roads, bridges, hospitals, schools, waterworks) the national bank can lend interest-free money to the government, as stated, for the purposes of the government's own capital expenditure. However, the capital projects can still, if wished, be built by the private sector, managed by the private sector, even owned by the private sector. Interest-free loans for public capital projects have been used by the Channel Island of Guernsey over the years. Guernsey, perhaps as a direct consequence, has minimal public debt. Malaysia is also believed to be experimenting with such loans and, in recent times, has achieved some remarkable feats of construction. Over the period 1939-74 (a particularly prosperous period) Canada used interest-free loans and, even today, many Canadian municipalities are demanding their use again to upgrade poor infrastructure. In the United States, 3,400 governmental bodies (such as civic authorities), and six State governments, support the idea of interest-free money for infrastructure. A national legislative proposal, introduced in the late 1990s, managed to reach Congress but was defeated by powerful vested interests. After 1935, New Zealand also used such loans for, inter alia, hydro-electric power schemes, railways and state housing and enjoyed a remarkably prosperous period as a consequence (Ashford 1999).

The state-issue of interest-free currency can also be used to transform the fractional reserve banking system, by making funds available to private banks, thus gradually increasing bank reserves to 100 per cent. This is in contrast, of course, to the debt-free monetary reform proposals mentioned above. Commercial retail banks will, therefore, be left with the duties of lending their own capital, interest-free reserves and (with permission) the deposits of their customers. Credit could then be provided to consumers and businesses on market principles, such as the ability to repay and the existence of collateral. ${ }^{\mathrm{ii}}$ Monies are repaid, firstly, to the commercial bank, which then repays the money to the central bank and the debt is retired. It is also assumed that these processes would involve much more state intervention (and regulation) of credit markets by monetary authorities, such as the imposition of lower interest rates, in the manner envisioned by Keynes (Keynes 1936). The threat of a bank-run would also be eliminated. The transition towards a 100 per cent fractional reserve system, therefore, offers (arguably) a more stable and resilient currency-issue than at present. Yet, interest-free 
money can also be used to spread the social ownership of capital as suggested by binary economists.

\section{Binary Economics}

Binary economics has been based upon the seminal work of Louis Kelso and, continues to be developed and promulgated by several adherents. ${ }^{\text {iii }}$ Their notion of the economic problem is that, to varying degrees, states have under-utilised resources, concentrated capital ownership and widespread wants. Since it is assumed that incomes are derived from both capital and labour (hence the term binary), they further suggest that labour incomes are only capable of purchasing a proportion of total output. New capital investment and the state consume a further portion and the rest is hoarded, leaving credit expansion to aid the sustainability of the capitalist order. This is regarded as entirely unsatisfactory, since it perpetuates capitalist crises and uneven development (Kelso 1958). Their proposals therefore aim to use interestfree loans to create 'effective participation' by broadening the ownership base of existing productive capital, and encouraging the formation of new capital with a broader social ownership. ${ }^{\text {iv }}$ The measures are also expected to be implemented within the confines of the present functioning of the capitalist order, with minimal disruption (see Figure 1.1). The concentration of capital ownership is therefore discouraged, and the use of credit diminished. Debt principal is to be paid from incomes (in the form of dividends) derived from the capital acquisition and, when the monies are repaid they are cancelled thus leaving an ongoing income for the capital recipient. It is argued that this would also be counter-inflationary providing there is spare capacity and that money expansion is matched by new production. The national bank could then become the source of newly-created money for the purpose of spreading the income from the real economy to every person in society. In the case of private corporations, a key condition for the receipt of interest-free loans could be that the investment finance is associated with the creation of new shareholders, thereby distributing the ownership of new capital assets throughout society. In practice, this means that not only workers but people in the dependent population (such as women, carers students or children) may be provided with a basic income, thus revolutionizing the current taxation system. ${ }^{\mathrm{v}}$

It is not suggested, of course, that the proposals outlined in this chapter are a complete solution to the periodic financial crises that tend to occur in the present monetary order but, it is hoped, they should be able to make a significant contribution towards monetary resilience. The greater the proportion of interest-free credit money in circulation, for instance, the less likely it is for a default crisis to occur, with its associated ramifications. 
Figure 1.1 Binary Proposals for the Interest-Free Issue of Money

Interest-free loans for productive purposes come from

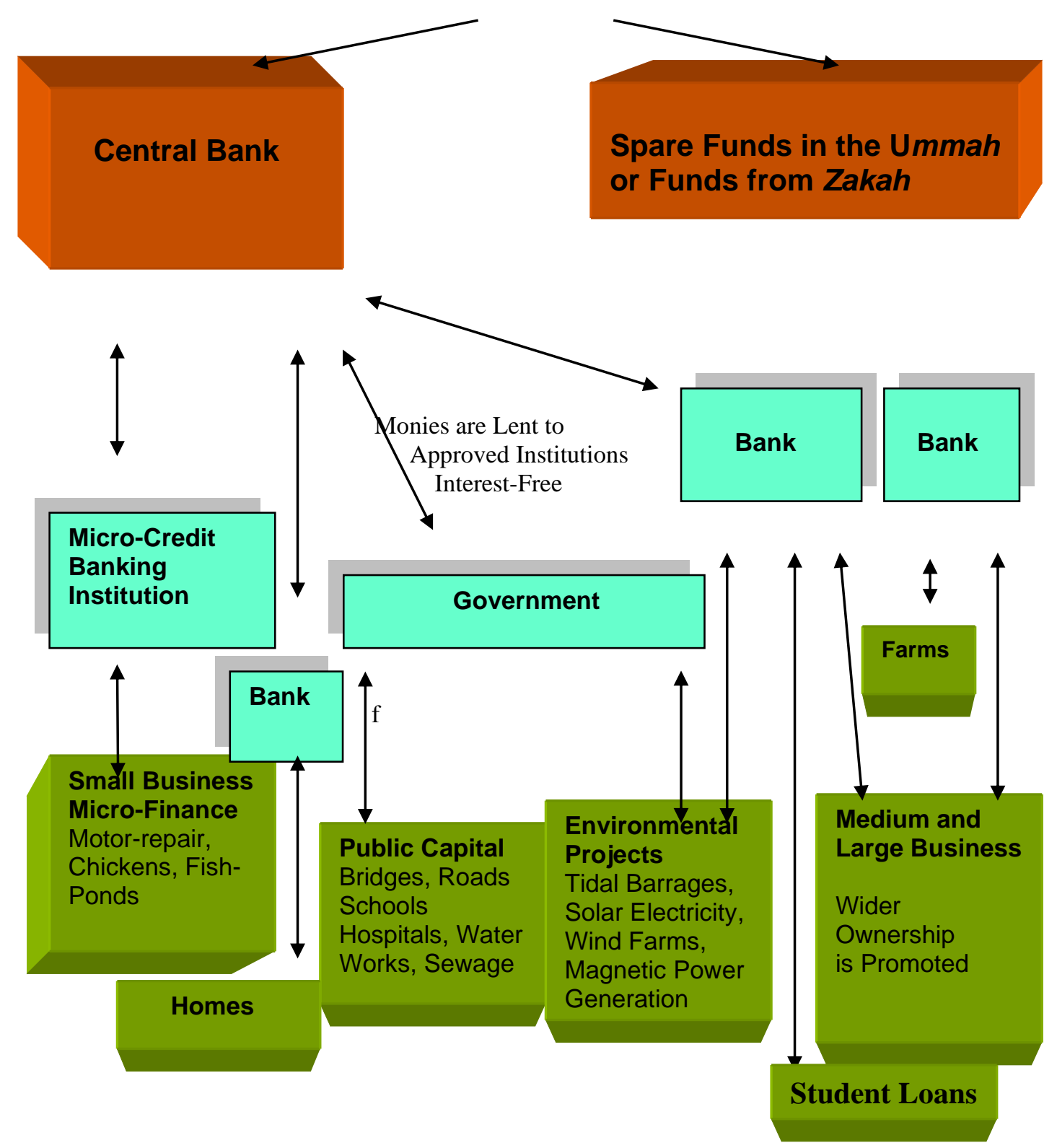

\section{REFERENCE}

Adams, P. (1991). Odious Debts: Loose Lending, Corruption and the Third World's Envionmental Legacy, Earthscan.

Ashford, R. S., Rodney (1999). Binary Economics: The New Paradigm. Lanham, Maryland, University Press of America.

Brown, E. H. (2007). The Web of Debt. Baton Rouge, Third Millenium Press.

El Diwany, T. (2003). The Problem with Interest 2nd Ed. Birmingham, Kreatoc. 
El Gamal, M. A. (2006). Islamic Finance: Law, Economics and Practice, Cambridge University Press.

Friedman, M. (1956). Studies in the Quantity Theory of Money. Chicago, University of Chicago Press.

Helleiner, E. (1994). States and the Re-emergence of Global Finance: From Bretton Woods to the 1990's, Cornell University Press.

Howells, P. B., Keith (2008). Economics of Money, Banking and Finance: 4th Edition. Gosport, Pearson.

Huber, J. R., James (2000). Creating New Money: A Monetary Reform for the Information Age. London, New Economics Foundation.

Kelso, L. O. A., Mortimer. J (1958). The Capitalist Manifesto. New York, Random House.

Kennedy, M. (1995). Inflation and Interest Free, New Society Publisher.

Keynes, J. M. (1936). The General Theory of Employment, Interest and Money, Macmillan. Lenin, V. (1996). Imperialism: The Highest Stage of Capitalism. Bristol, Pluto.

Marx, K. (1976). Capital: Volume One. St Ives, Penguin.

McConnachie, A. (2006). Clarifying Our Money Reform Proposals: A Report for the Tenth Annual Bromsgrove Conference. Bromsgrove Conference, Bromsgrove, England.

Mouatt, S. (2008). "Evaluating Stephen Zarlenga's Treatment of Historical Monetary

Thought." International Journal of Social Economics 35(11).

Pettifor, A. (2006). The Coming First World Debt Crisis. Chippenham, Palgrave, Macmillan.

Rochon, L.-P. (1999). "Endogenous Money." Journal of Economic Issues 33(1).

Shakespeare, R. C., Peter (2002). Seven Steps to Justice. Chippenham, New European Publications.

\footnotetext{
i It could be argued that the 'impossibility contract' does not actually exist since $a$ priori any interest payment paid is then transformed in to financial sector income and, if there is sufficient circulation before the next debt repayment, future principal and interest payments could be made from existing monies. However, this would still not cover the last repayment of a given time-based debt contract and, therefore, the 'impossibility contract' remains valid. In addition, it is unlikely that sufficient circulation from creditor to debtor will always occur.

ii At present, monetary discipline is maintained by the state by ensuring (through the audit process) that retail banks are liable for any default. It is envisaged that this practice would remain the same.

iii The Washington Centre for Economic and Social Justice is at the forefront of the present movement advocating spreading capital ownership from the work of Kelso. Professor Rodney Shakespeare, conversely, has developed the binary ideas to include interest-free lending for public expenditure, microcredit, social housing, student loans, environmental projects and basic income.

iv In the early 1950s, Taiwan used these basic binary mechanisms to spread the ownership of the farms.

${ }^{v}$ It could be argued that it is very difficult to posit the existence of universal human rights when individuals do not have sufficient income to enjoy a minimal basic living standard.
} 